\title{
Understanding Resiliency in Coastal Areas: A Review Paper from Sociological Perspectives
}

\author{
Sohela Mustari ${ }^{1}$, A.H. M. Zehadul Karim ${ }^{1}$ \\ ${ }^{1}$ Department of Sociology and Anthropology, IRKHS, International Islamic University, Malaysia (IIUM), Gombak, \\ Malaysia. \\ Corresponding : Sohela Mustari, Department of Sociology and Anthropology, IRKHS, International Islamic University, \\ Malaysia (IIUM), Gombak, Malaysia.
}

Received: January 4, 2015

Accepted: January 16, 2015

Available online: April 14, 2015

doi:10.11114/ijsss.v3i3.765

URL: http://dx.doi.org/10.11114/ijsss.v3i3.765

\begin{abstract}
Based on secondary data, this paper tries to identify the resiliency of coastal people. Existing literature emphasizes that resiliency means a kind of adaptation where societal members can adjust themselves to a different environment. It is also discovered in prevailing literature that resiliency as a concept is not well-described in sociology. Thus, in this review, it attempts to examine resiliency from sociological perspectives. To do this, previous research on coastal society is focused on to know their resilience capacity in detail.
\end{abstract}

Keywords: Resiliency, Coastal areas, Natural disasters, Environment, Climate change

\section{Introduction}

Crawford S. Holling (1973) was the first who coined the term 'resilience' and it has been mentioned that this term resilience was first used in ecological literature (as cited in Gunderson, 2000). Nowadays, this term is widely used by social scientists to explain the social-ecological systems of human society (Carpenter, Westley \& Turner, 2005). In this regard, some researchers define 'resilience' as a dynamic and integrated system; specifically, it integrates a social-ecological system (Folke, 2006; Armitage \& Plummer, 2010). The first definition of 'resilience' from Holling (1973: p. 1) was:
Individuals die, populations disappear, and species become extinct. That is one view of the world. But another view of the world concentrates not so much on presence or absence as upon the numbers of organisms and the degree of constancy of their numbers. These are two very different ways of viewing the behavior of systems and the usefulness of the view depends very much on the properties of the system concerned.

Though the definition of 'resilience' first emerged about 40 years ago in 1973, it can be admitted that resilience is a concept which has no well accepted definition as yet. Many researchers define resilience differently from their own research interest as they do not have any fixed and formal definition. For instance, Walker et al. (2004) define resilience mostly from the environmental science perspective. These researchers consider resilience and adaptation as similar in terms of their meaning. However, they differ only because of their different use by different researchers. They consider the environment as a dynamic process. According to their definition, the environment works like a system which has a natural capacity to get back its previous condition to work and perform the functions like before. To get back its resilience, four phases help the system. These phases are latitude, resistance, precariousness and panarchy. Collectively, with all these four components, a better resilient system can be achieved. Walker et al. (2004) suggest that the strategies to bring resilience to a system is not uniformed across other systems. Depending on the nature of change and both the indigenous and regional settings, the mechanisms for resilience should be considered. In this regard, Walker et al. (2004: p. 6) define resilience as:

the capacity of a system to absorb disturbance and reorganize while undergoing change so as to still retain essentially the same function, structure, identity, and feedbacks-in other words, stay in the same basin of attraction.

Adger (2000) argues that the concept of resilience is mostly and widely used in ecological science. However, in his 
paper, resilience is connected to both social and ecological arrangements. Therefore, it is predicted that without ecological resilience, it is not possible to establish the social resilience of a society. According to this author, social resilience is a kind of adaptation where an individual or society can adjust to the changed environment. Adger (2000) talks about the coastal people and their resiliency. He states that the vulnerability that a coastal society experiences due to natural disasters can be overwhelmed by decreasing negative impacts of land degradation, agricultural production and changed livelihood systems. Some researchers (Adger, 2000; Cutter, Boruff \& Shirley, 2003; Pelling, 2003; Mathbor, 2007) demonstrate that local people's indigenous knowledge and their social networks can be used as weapons for bracing their resiliency. Mathbor (2007) specifies on social networking, social solidity and social collaboration to bring resiliency to coastal life by reducing vulnerability due to natural disasters. He also talks about those societies which are well-prepared socio-culturally to mitigate the sufferings that can easily bring about their resiliency than others. Mathbor (2007: 357- 358) in this article states:

Communities need to be prepared for natural and human-made disasters because these can strike anywhere, regardless of location, culture or history. Communities that are well trained culturally, socially and psychologically are better prepared and are more effective in responding to the aftermath of disasters.

Adger et al. (2003) predict that the trend of world climate change will remain in the near future as well. Unfortunately, it is not possible to predict the nature and effect of this climate change. Based on their research, the impact of climate change on societal issues is certainly complex in nature, particularly for developing countries. In this paper, the researchers mostly focus on adaptation which is a process to ease the sufferings that arise from climate change. However, people should depend on the benefits of the new opportunities that are available for them. Historically, coastal societies used migration as an option of their adaptation to natural disasters. This is because they have limitation of resources to cope with. Presently, people from many developing countries are utilizing their capacity by migrating locally or internationally (Adger et al., 2003).

Adger et al. (2005) continue to work on societal resiliency and migration. In their paper, they emphasize on migration for societal resilience. They say that due to natural disasters, the previous ecological settings do not function anymore. In this situation, if the people want to sustain their living, they must provide information to create awareness and to deal with nature. Moreover, there are various socio-political networks to boost the resources which bring socio-ecological resilience. Adger et al. (2005) in this regard say, "Resilient social-ecological systems incorporate diverse mechanisms for living with, and learning from, change and unexpected shocks" (p. 1036). In another place in this paper, they state:

The capacity of coastal ecosystems to regenerate after disasters and to continue to produce resources and services for human livelihoods can no longer be taken for granted. Rather, socio-ecological resilience must be understood at broader scales and actively managed and nurtured. Incentives for generating ecological knowledge and translating it into information that can be used in governance are essential. Multilevel social networks are crucial for developing social capital and for supporting the legal, political, and financial frameworks that enhance sources of social and ecological resilience (Adger et al., 2005: p. 1039).

Miller et al. (2010) discuss two related concepts; vulnerability and resilience. Both natural and social scientists explain these two concepts differently according to their respective disciplines. The natural scientists mostly explain these through ecological-biophysical dimensions; on the other hand, social scientists focus on social-political dimensions. These authors thus confirm that in recent times, research on vulnerability and resilience has increased more in the social sciences field and both vulnerability and resilience have been combined to ensure a more holistic research. In their paper, they relate both ecology and social sciences and show that natural disasters like drought or floods keep causing economic crises but based on these changes, people gradually adjust to the changing nature of economic crisis. Miller et al. (2010) claim, "Resilience has been used in two ways in ecology, one focusing on recovery and return time following a disturbance, the other focusing on how much a system can be disturbed and still persist without changing function" (p. 3). Meanwhile, UNISDR (2009:p.28) defines resilience in a general way:

The ability of a system, community or society exposed to hazards to resist, absorb, accommodate to and recover from the effects of a hazard in a timely and efficient manner, including through the preservation and restoration of its essential basic structures and functions.

\section{Coastal Areas and Resiliency}

Ingram, Franco, Rio and Khazai (2006) mention that the coping activities of coastal people depend mostly on prior defense strategies which are locally and nationally available. They determine the policies and rely on available aids and short-term resurgence strategies which are undoubtedly important but newly developed long-term strategies are also 
highly needed and these should be based on the vulnerability of different risk holders. Short-term strategies like providing food or aids are too tedious as they are focused mostly on protected asylum and subsistence activities. However, long-term strategies deal with multi-sectors centering on sustainable use of coastal assets, shore up livelihood and amplification in communication.

The article by Pomeroy et al. (2006) focuses on long term strategies to bring resiliency to the coastal people. They claim that these people should branch out the livelihood options so that they can survive from calamities like a tsunami. Apart from this, transformation or introduction of new strategies to adjust people to the old livelihood options has also been suggested. More specifically, for coastal recovery entire restoration and coordination of socio-economic and environmental livelihoods have been recommended. Coastal people should have their own cognizance and worldview to bring their own social resiliency. For example, if disasters destroy any social organization, it should be re-established or newly established by the community. Pomeroy et al. (2006) evaluated the after-effects of the 26 December 2004 Tsunami in Asia and assessed its impacts since then. They said that the tsunami-affected people of Asia were given work and aid which were not sufficient solutions for the community. These work and aid were only short-term solutions. Resilient long-term solutions were required as they sought the origin of their vulnerability. From that assessment, the researchers came to a conclusion that the safeguard strategies available for this community were not enough as most of the strategies were temporary which can only overcome their instant sufferings. Without knowing the root causes of coastal vulnerabilities, problems cannot be solved, hence long-term strategies to harmonize all sectors to initiate their resilience are needed (Pomeroy et al., 2006)).

Badjeck et al. (2010) also discuss the resilience of coastal society. In their paper, they indicate that climate change has both negative and positive impacts on society. People can get back their resilience as climate change generates alternatives for them to utilize with apt procedures. However, to utilize these alternatives, there should be a holistic approach in reducing vulnerability. This paper highlights the fact that to reduce vulnerability and to be resilient on their livelihoods, society needs to develop socio-ecological advancement and introduce livelihood diversity. Migration is highly favoured, which can be a source of expanding living expenses.

Shamsuddoha \& Chowdhury (2007) also state that migration brings flexibility into people's social life. Along with migration, the researchers mention that to reduce the society's vulnerabilities caused by natural disasters, the inhabitants need to change their livelihood strategies or increase their capacity ${ }^{1}$ building activities or accept displacement activities through migration. This statement is supported by many researchers who say that to bring resiliency to coastal life, people can look for alternative livelihoods (Quadir \& Iqbal, 2008; Thang, Ngoc \& Anh, 2009; Adger et al., 2002). An agriculture-based coastal community can change to shifting agriculture and multiple cropping to ease their vulnerabilities and to convey resiliency in their livelihoods (Nyasimi et al., 2007).

Agrawala and Carraro (2010) conducted research on two climatically vulnerable countries of south Asia: Bangladesh and Nepal. They found micro finance as a source of bringing resiliency to these people. This paper analyzed the portfolio of 22 micro-finance providing organizations of these countries in employment and income making activities, agriculture, water and sanitation, well-being, and infrastructural development. Though this micro-finance has some drawbacks, it is very much effective in reducing vulnerability and creating resiliency. Klein, Nicholls \& Thomalla (2003: p. 38) compare the resiliency process in two countries:

It is therefore not surprising that most industrialised countries have higher adaptive capacities than developing countries. For example, Bangladesh and The Netherlands share a similar physical susceptibility to sea-level rise, but Bangladesh lacks the economic resources, technology and infrastructure that The Netherlands can call on to respond to the potential impacts.

Likewise, Handmer, Dovers \& Downing (1999) mention that to create resiliency in a community, institutional capacity is very significant. It means, society should make preparations and have the capacity to absorb and adjust to the changing situation. Furthermore, as future vulnerabilities are not predictable, policy should be taken for the health and proper growth of that society. Though it is possible to minimize the geo-physical events, it is not possible to eliminate them absolutely. Proper socio-economic policies should be implemented so that society can adjust itself to the changes.

\section{Socio-Demographic Factors and Resiliency}

Researchers (Badjeck et al., 2010) found that resilience ${ }^{2}$ differ from person to person, profession to profession and locality to locality. According to them, the reaction towards climate change and its impacts are not unique for all

\footnotetext{
1 "The combination of all the strengths, attributes and resources available within a community, society or organization that can be used to achieve agreed goals" (UNISDR, 2009: p.5).

2 "Resilience is relatively a new phenomenon in the disaster management discourse though the use of the term is observed since 1991 in Bangladesh to refer to the bounce back capacity of people after any disaster" (Rashid, 2013: p. 31).
} 
communities.

Ingram et al. (2006) also did their research on the way tsunamis affected people of Sri Lanka where they found huge inequality and differences in the nature of vulnerabilities and resiliency among the affluent and the non-affluent people. They found these inequalities in the way the people use their lands and professions and whether or not they have insurance. These authors declared that the monsoon climate and geographical position caused these Sri Lankan people to be vulnerable environmentally. This geo-climate trend also caused tsunamis in this area. However, the tsunamis start from a geographical point and spread into the socio-economical context. The socio-economic and environmental degradation happen to this community through trailing of residences, lodges, small industries, educational institutes, sickbays, coral reefs, sandbanks, mangrove areas, coastal tree-plantings, water, palm farms and agricultural schemes. As a consequence, naturally deprived people had fewer resources to rely on to cope with the natural hazards (Ingram et al., 2006)). In this context, another researcher (Baker, 2012: p. 8) claims:

The poor typically settle in areas undesirable to others and thus affordable. This includes informal settlements on precarious land, at high risk from land-slides, sea-level rise, and flooding. These neighborhoods are made even more vulnerable by overcrowded living conditions, unsafe housing, inadequate nutrition, poor health and lack of safety nets. When a disaster hits, impacts can include the loss of basic services, damage or destruction to homes, reduction or loss of livelihoods, threats to food security, and the rapid spread of malnutrition and water and vector-borne diseases.

The research by Dolan and Walker (2006) is a case study based on northeast Graham Island, Haida Gwaii (Queen Charlotte Islands), British Columbia which is considered as one of the most susceptible coasts of Canada. In this paper, the concept of vulnerability and the adaptability of the community were the key focus. It was found that climate change and its effects are not equal for all. This paper suggests for a coordinated framework of vulnerability and resiliency. The paper on Haida Gwaii Island affirms that not only socio-historical pattern but also socio-demographic information of individuals and community, their resource pattern, resource ownership and socio-economic/political empowerment are also important in making them resistant. This paper by Dolan and Walker (2006) insists on community adaptation to produce their resiliency where local and indigenous knowledge should be the primary sources of information along with an interaction between multiple disciplines, organizations, policy-makers, resource users and inhabitants.

\section{Conclusion}

Finally, it can be said that the resiliency of different people differ according to their access to assets, income, class, inequality and also due to other demographic characteristics (Kleih et al., 2003; Shamsuddoha \& Chowdhury, 2007; Deb, 2009; Melton, 2008; Rahman et al., 2007; Paul, 2011; Quadir \& Iqbal, 2008).

In conclusion, it can be said that to bring resiliency to coastal lives, the social, economic, environmental and infrastructural institutions must be synchronized so that they can deter all vulnerabilities and then diversify coastal livelihood. Moreover, it is also necessary to coordinate the relationship among local, national, or international sectors to bring resiliency to coastal livelihood (Kesavan \& Swaminathan, 2006; Shamsuddoha \& Chowdhury, 2007; Haque, 2006). Mertz et al. (2009: p. 750) state:

In agriculture, for example, wealthy farmers are more likely to benefit from a more flexible choice of seed and farming location that might be needed if droughts (or floods) become more frequent. At the same time, it should be recognized that investments with a long lifetime (e.g., in infrastructure, water systems, and energy conversion) should be given special attention in climate-proofing efforts, because large investments are at stake and climate change is expected to develop further over their lifetimes.

\section{References}

Adger, W. N. (2000). Social and ecological resilience: are they related?.Progress in human geography, 24(3), $347-364$. http://dx.doi.org/10.1191/030913200701540465

Adger, W. N., Kelly, P. M., Winkels, A., Huy, L. Q., \& Locke, C. (2002). Migration, remittances, livelihood trajectories, and social resilience. AMBIO: A Journal of the Human Environment, 31(4), 358-366. http://dx.doi.org/10.1639/0044-7447(2002)031[0358:MRLTAS]2.0.CO;2

Adger, W. N., Huq, S., Brown, K., Conway, D., \& Hulme, M. (2003). Adaptation to climate change in the developing world. Progress in development studies, 3(3), 179-195. http://dx.doi.org/10.1191/1464993403ps060oa

Adger, W. N., Hughes, T. P., Folke, C. Carpenter, S. R., \& Rockström, J. (2005). Social-ecological resilience to coastal disasters. Science, 309(5737), 1036-1039. http://dx.doi.org/10.1126/science.1112122

Agrawala, S., \& Carraro, M. (2010). Assessing the role of microfinance in fostering adaptation to climate change. 
Armitage, D. R., \& Plummer, R. (Eds.). (2010). Adaptive capacity and environmental governance. Berlin, Germany: Springer. http://dx.doi.org/10.1007/978-3-642-12194-4

Badjeck, M. C., Allison, E. H., Halls, A. S., \& Dulvy, N. K. (2010). Impacts of climate variability and change on fishery-based livelihoods. Marine Policy, 34(3), 375-383. http://dx.doi.org/10.1016/j.marpol.2009.08.007

Baker, J. L. (Ed.). (2012). Climate change, disaster risk, and the urban poor: cities building resilience for a changing world. World Bank Publications. http://dx.doi.org/10.1596/978-0-8213-8845-7

Carpenter, S. R., Westley, F., \& Turner, M. G. (2005). Surrogates for resilience of social-ecological systems. Ecosystems, 8(8), 941-944. http://dx.doi.org/10.1007/s10021-005-0170-y

Cutter, S. L., Boruff, B. J., \& Shirley, W. L. (2003). Social vulnerability to environmental hazards. Social science quarterly, 84(2), 242-261. http://dx.doi.org/10.1111/1540-6237.8402002

Deb, A. K. (2009). 'Voices of the Fishantry': Learning on the Livelihood Dynamics from Bangladesh (Doctoral dissertation, University of Manitoba).

Dolan, A. H., \& Walker, I. J. (2006). Understanding vulnerability of coastal communities to climate change related risks. Journal of Coastal Research, 1316-1323.

Folke, C. (2006). Resilience: The emergence of a perspective for social-ecological systems analyses. Global environmental change, 16(3), 253-267. http://dx.doi.org/10.1016/j.gloenvcha.2006.04.002

Gunderson, L. H. (2000). Ecological resilience--in theory and application. Annual review of ecology and systematics, 425-439. http://dx.doi.org/10.1146/annurev.ecolsys.31.1.425

Handmer, J. W., Dovers, S., \& Downing, T. E. (1999). Societal vulnerability to climate change and variability. Mitigation and adaptation strategies for global change, 4(3-4), 267-281. http://dx.doi.org/10.1023/A:1009611621048

Haque, S. A. (2006). Salinity problems and crop production in coastal regions of Bangladesh. Pak. J. Bot, 38(5), 1359-1365.

Holling, C. S. (1973). Resilience and stability of ecological systems. Annual review of ecology and systematics, 1-23. http://dx.doi.org/10.1146/annurev.es.04.110173.000245

Ingram, J. C., Franco, G., Rio, C. R. D., \& Khazai, B. (2006). Post-disaster recovery dilemmas: challenges in balancing short-term and long-term needs for vulnerability reduction. Environmental Science \& Policy, 9(7), 607-613. http://dx.doi.org/10.1016/j.envsci.2006.07.006

Kesavan, P. C., \& Swaminathan, M. S. (2006). Managing extreme natural disasters in coastal areas. Philosophical Transactions of the Royal Society A: Mathematical, Physical and Engineering Sciences, 364(1845), 2191-2216. http://dx.doi.org/10.1098/rsta.2006.1822

Kleih, U., Alam, K., Dastidar, R., Dutta, U., Oudwater, N., \& Ward, A. (2003). Livelihoods in Coastal Fishing Communities, and the Marine Fish Marketing System of Bangladesh, synthesis of participatory rural appraisals in six villages, and assessment of the marketing system. NRI Report No 2712, Project A1004.

Klein, R. J., Nicholls, R. J., \& Thomalla, F. (2003). Resilience to natural hazards: How useful is this concept?. Global Environmental Change Part B: Environmental Hazards, 5(1), 35-45. http://dx.doi.org/10.1016/j.hazards.2004.02.001

Mathbor, G. M. (2007). Enhancement of community preparedness for natural disasters the role of social work in building social capital for sustainable disaster relief and management. International Social Work, 50(3), 357-369. http://dx.doi.org/10.1177/0020872807076049

Melton, G. (2008). Assessing coastal erosion vulnerability: A case study of Georgetown County, South Carolina (Doctoral dissertation, University of South Carolina).

Mertz, O., Halsnæs, K., Olesen, J. E., \& Rasmussen, K. (2009). Adaptation to climate change in developing countries. Environmental management, 43(5), 743-752. http://dx.doi.org/10.1007/s00267-008-9259-3

Miller, F., Osbahr, H., Boyd, E., Thomalla, F., Bharwani, S., Ziervogel, G., \& Nelson, D. (2010). Resilience and vulnerability: complementary or conflicting concepts. Ecology and Society, 15(3), 11.

Nyasimi, M., Butler, L. M., Burras, L., Ilahiane, H., Schultz, R., \& Flora, J. (2007). Differentiating livelihood strategies among the Luo and Kipsigis people in western Kenya. Journal of Ecological Anthropology, 11, 44. http://dx.doi.org/10.5038/2162-4593.11.1.3 
Paul, B. K. (2011). Environmental hazards and disasters: contexts, perspectives and management. UK: John Wiley \& Sons. http://dx.doi.org/10.1002/9781119979616

Pelling, M. (2003). The vulnerability of cities: natural disasters and social resilience. Earthscan.

Pomeroy, R. S., Ratner, B. D., Hall, S. J., Pimoljinda, J., \& Vivekanandan, V. (2006). Coping with disaster: Rehabilitating coastal livelihoods and communities. Marine Policy, 30(6), 786-793. http://dx.doi.org/10.1016/j.marpol.2006.02.003

Quadir, D. A., \& Iqbal, M. A. (2008). Tropical cyclones: impact on coastal livelihoods: investigation of the coastal inhabitants of Bangladesh. IUCN Bangladesh Country Office.

Rahman, A., Alam, M., Alam, S. S., Uzzaman, M. R., Rashid, M., \& Rabbani, G. (2007). Risks, vulnerability and adaptation in Bangladesh. Human Development Report, 8.

Rashid, A. M. (2013). Understanding Vulnerability and Risks. In Disaster Risk Reduction Approaches in Bangladesh, 23-43. Springer Japan. http://dx.doi.org/10.1007/978-4-431-54252-0_2

Shamsuddoha, M., \& Chowdhury, R. K. (2007). Climate change impact and disaster vulnerabilities in the coastal areas of Bangladesh. COAST Trust, Dhaka.

Thang, T. N., Ngoc, K. T. T., Anh, N. T. N. (edt) (2009). Building Resilience Adaptive Strategies for Coastal Livelihoods most at risk to climate change impacts in Central Viet Nam. Vietnam Ministry of Natural Resources and Environment (MONRE) and United Nations Development Programme (UNDP).

The United Nations Office for Disaster Risk Reduction (UNISDR) (2009). 2009 UNISDR Terminology on Disaster Risk Reduction. Published by the United Nations International Strategy for Disaster Reduction (UNISDR) Geneva, Switzerland, May 2009.

Walker, B., Holling, C. S., Carpenter, S. R., \& Kinzig, A. (2004). Resilience, adaptability and transformability in social--ecological systems. Ecology and Society, 9(2), 5.

\section{(cc) $\mathrm{BY}$}

This work is licensed under a Creative Commons Attribution 3.0 License. 